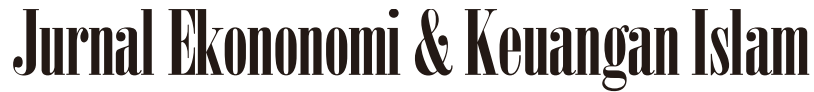

\section{The potential of digital banking to handle the Covid-19 pandemic crisis: Modification of UTAUT model for Islamic finance industry}

\author{
Alex Fahrur Riza \\ Faculty of Islamic Economics and Business UIN Sunan Kalijaga, Yogyakarta, Indonesia
}

\section{Article History \\ Received : 21 September 2020 \\ Revised : 10 November 2020 \\ Accepted : 27 December 2020 \\ Published : 11 January 2021 \\ Keywords: \\ UTAUT2, Trust, Satisfaction, \\ Digital Banking, COVID-19 \\ DOI: \\ https://doi.org/10.20885/JEKI.vol 7.iss1.art1}

\section{JEL Classification:}

D01, D10, D12

\section{Corresponding author:}

alex.riza@uin-suka.ac.id

\section{Paper type:}

Research paper

\section{Cite this article:}

Riza, A.F. (2021). The potential of digital banking to handle the Covid19 pandemic crisis: modification of UTAUT model for Islamic finance industry. Jurnal Ekonomi dan Keuangan Islam, 7(1), 1-16. https://doi.org/10.20885/JEKI.vol 7.iss1.art1

\begin{abstract}
Purpose - This research aims to examine the driving factors for the adoption of digital banking of Islamic banks during the COVID-19 pandemic, to explore the development of specific UTAUT2 model for Islamic financial technology, and to investigate factors that need to be improved in digital banking services of Islamic banks based on customer perspectives.
\end{abstract}

Methodology - This research is divided into three. The first study is an empirical testing of UTAUT2 model modified by adding trust and satisfaction variables. The second study is an exploratory study of potential construct for the development of UTAUT model in Islamic Financial Technology. Third, it is an exploratory study aiming to identify problems and to search for policy advice to improve digital banking service of Islamic banks. This research used self-administered survey that involved 845 respondents from several cities in Indonesia. Open and closed question design was used to obtain complementary data. After that, the data were analyzed using SEM-PLS 7.0 and SPSS 23.

Findings - The results of this study shows that people have trust, acceptance, and satisfaction on the digital banking service of Islamic banking technology. There are seven hypotheses in this study supported empirically. There are 20 factors that became the main reasons of customers to use the digital banking service of Islamic banking technology and 32 factors that needed to be improved by Islamic banks based on the customers' perspective. After that, the researcher grouped them into seven policy advices for digital banking service of Islamic banking technology, where these factors can be taken into consideration to improve the competitiveness of the Islamic Finance Industry in Indonesia.

Originality - In addition to testing and modifying the UTAUT2 model during the COVID-19 pandemic, this study also explores the possibility of new variables arising from customers' perception, where the data will be used to submit new variables/models that are more specific to the acceptance of Islamic financial technology. Furthermore, this study also aims to explore several obstacles in the digital banking service of Islamic banking technology.

\section{Introduction}

The world, including Indonesia, is hit by a pandemic that has damaged social and economic sector due to the emergence of COVID-19. World leaders are trying to adopt various strategies to prevent the transmission of this new type of corona virus even though they still face failures (Amir \& Amir, 2020). There have been more than 16 million positive confirmed cases of corona until July 2020 in 215 countries (worldometer.info, 2020). The World Health Organization 
(WHO) said that there had been 91,751 confirmed cases and 4,459 deaths in Indonesia until 22 July 2020. This pandemic also causes uncertainty and overthrows the global finance, politic, geopolitic, and socio-economic chains (Roubini, 2020; Winarsih et al., 2020; Sembiring, 2020). Every country must strive to overcome this dilemma between saving lives and the economy (Amir \& Amir, 2020; Syed et al., 2020).

During this pandemic, not all economic sectors have slumped. Dcode Economic \& Financial Consulting (DEFC, 2020) conveys several industries that have the potential to develop during a pandemic, namely E-commerce and ICT. In this era, many organizations allocate resources to use technology both to obtain competitive advantage and to attract consumers (Nawaz et al., 2020). Technology has a huge impact on supporting human activities (Wijayanti \& Riza, 2017) especially during the lockdown and physical distancing. According to Dcode, the financial service industry is experiencing a downturn, but this is in contrast to digital banking services. The International Monetary Fund (IMF) states that digital financial services are faster, more efficient, and typically cheaper than traditional banking services (Sahay et al., 2020). Consequently, banking sector gets significant benefits from digital banking technology innovation by providing higher quality and faster services to customers (Nawaz et al., 2020; Riza, 2019).

During the COVID-19 pandemic, digital banking services applied a system of contactless and cashless transactions although non-cash transactions using ATM and Debit Card decreased by 4.7\% in March 2020. Bank Indonesia (BI) noted that the volume of digital banking transactions since April 2020 has increased significantly by 37.35\% (year over year). BI Governor, Perry Warjiyo, revealed that the increase in economic transactions through digital has increased rapidly by $60.8 \%$ compared to the same period in 2019 because digital banking makes it easier for people whose activities have increased virtually (finance.detik, 2020). Electronic money transactions have grown by $67.9 \%$ since March 2020 compared to the 2019 period (cnbcindonesia, 2020). This development indicates the increasing need for digital banking and financial transactions by the community.

Increasing digital financial inclusion will facilitate the deployment of governmentsupported measures to address this crisis (Sahay et al., 2020). Bank operational risk management must be carried out properly to improve service performance and superior innovation in an unstable environment (Sembiring, 2020; Disemadi \& Shaleh, 2020). It is shown that the use of banking technology has a positive impact (Nam et al., 2016; Riza \& Hafizi, 2019; Wijayanti \& Riza, 2017). Since the launching of the Branchless Banking system in 2013, it has been proven that digital banking services have succeeded in reaching the unbanked and underbanked people (Bank Indonesia, 2019).

To measure the level of digital banking adoption during the pandemic, researchers used Unified Theory of Acceptance and Use of Technology 2 (UTAUT2) (Venkatesh et al., 2012). This model is a development of UTAUT, which is used to understand the acceptance and use of information technology (Venkatesh \& Davis, 2000; Venkatesh et al., 2007; Venkatesh et al., 2003). This model is chosen for its quite robust ability in predicting the acceptance and use of technology and it has been digitized and published by more than 60 reputable international journals (Venkatesh et al., 2016). However, previous studies regarding technology in the Islamic Finance Industry are still limited to the implementation of the UTAUT model and the addition of new variables for model development (Hassanudin et al., 2019; Johar \& Suhartanto, 2019; Thaker et al., 2019; Raza et al., 2019). However, this study is different because, in addition to testing the UTAUT model during the pandemic, this study also adds trust and satisfaction variables, and explores the possibility of new variables arising from customer perceptions by presenting open-ended questions before closed questions on the questionnaire. After that, the data will be used to submit new variables/models that are more specific to the acceptance of Islamic financial technology. This is in line with the recommendation Venkatesh et al. (2016) to develop the UTAUT model for new concepts and phenomena. Thus, the research questions can be formulated as follows:

1. What drives customers' intention to adopt and to use the digital banking of Islamic banks during the COVID-19 pandemic?

2. What are the potential constructs for the UTAUT model development that is specific to Islamic financial technology? 
3. What factors need to be improved in the digital banking services of Islamic banks based on customers' expectation?

To answer these questions, the researchers divided this study into three. In the first study, the UTAUT model was tested on digital banking services of Islamic banks. The second one is exploratory study that focused on potential constructs for the UTAUT model development in Islamic financial technology. The third one is exploratory study that aims to search for obstacles and come up with policy advice to improve the digital banking services in Islamic banks.

\section{Literature Review}

\section{Digital Banking}

Digital Banking is a new term in banking industry in Indonesia (Riza \& Hafizi, 2019). Digital banking implements all banking services and operations in digital devices (Nguyen et al., 2018). According to the Regulation of Financial Services Authority (OJK) No.12/POJK03/2018, digital banking service is defined as an electronic banking service developed by optimizing the use of customers' data in order to serve customers more quickly and easily based on their needs. It can be done completely independently by the customers with attention to the security aspect, where the digital banking service is done through internet banking, mobile banking, SMS banking, and phone banking. However, this definition is still limited to activities/services and does not include the neobank concept defined by IBM, the concept of open banking based on the Application Programming Interface by Capgemini, and the concept of digital banking model 2025 proposed by Gasser (2017).

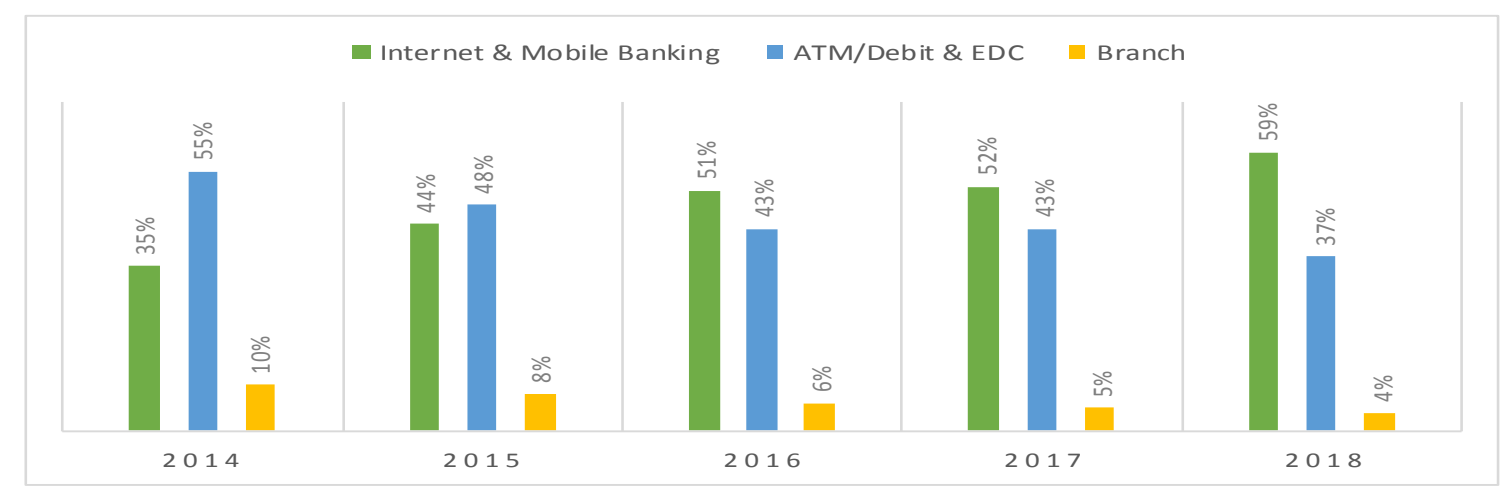

Source: (Institute for Development of Economics and Finance (INDEF), 2018)

Figure 1. Banking Transaction based on Frequency during $2014-2018$

Banking transactions via digital system have increased drastically. This is shown by data from the Institute for Development of Economics and Finance (INDEF) in 2018, which shows that $41 \%$ of the frequency of transactions via mobile banking, $18 \%$ via internet banking, $37 \%$ via ATM/Debit, $5 \%$ via EDC, and $4 \%$ via transactions in branch offices only. It is shown that digital banking transactions have increased almost seven times compared to 2010 (katadata, 2020). The graph of the increase can be seen in Figure 1.

\section{Theoretical Foundation and Formulation of Hypothesis}

Unified Theory of Acceptance and Use of Technology (UTAUT) popularized by Venkatesh et al., (2003) is a theory that focuses on predicting technology adoption and use. The model development is carried out by combining eight theories explaining acceptance of technology, namely Theory of Reasoned Action (TRA), Technology Acceptance Model (TAM), the Motivational Model (MM), Theory of Planned Behavior (TPB), the Model of PC Utilization (MPCU), Innovation Diffusion Theory (IDT), the Social Cognitive Theory (SCT), and the Integrated Model of TAM and TPB. There are four constructs influencing the behavioral intention (BI) in using technology, namely Performance 
Expectancy (PE), Effort Expectancy (EE), Social Influence (SI), and Facilitating Condition (FC). After that, Venkatesh et al. (2012) expands it by adding three constructs consisting of Hedonic Motivation (HM), Price Value (PV), and Habit (Hb), so it becomes a UTAUT2 model.

In this first study, the researchers selected the constructs that best fit the context of digital banking service of Islamic banks and proposed two new constructs, namely customer trust (Akhtar et al., 2019; Alharbi, 2017; Giri \& Wellang, 2016) and Customer Satisfaction (Albashrawi et al., 2019; Chao, 2019; Rahi et al., 2019) for digital banking service of Islamic banks.

The behavioral intention (BI) is the desire to adopt the latest technology (Nawaz et al., 2020). This construct is considered a strong factor in determining individual acceptance of technology (Rahi et al., 2018; Venkatesh et al., 2012). PE is defined as the degree to which individuals believe that the use of technology will help gain advantage in their work. According to Venkatesh et al. (2003) PE requires the importance of using technology to improve performance. Literature review shows that $\mathrm{PE}$ is one of the most significant variables influencing behavioral intention to adopt and to use information systems (Alalwan, 2018) especially internet banking (Rahi et al., 2019) and mobile banking (Nawaz et al., 2020). Based on customers' perception, the better the performance of digital banking service, the higher the customers' intention to use it. Therefore, the hypothesis is proposed as follows:

H1: Performance Expectancy (PE) has a positive effect on behavioral intention (BI) in using digital banking service in Islamic banks.

Effort Expectancy (EE) is a variable that explains how easy it is for individuals to operate technology (Venkatesh et al., 2003b). Research by Aji et al., (2020) shows that the perceived ease of TAM significantly influences the behavioral intention to use technology. According to Hassanudin et al., (2019) the easier the use of internet banking, the higher the customers' adoption rate will be. If the use of technology makes customers' lives simpler and easier with less interaction with humans, it will increase the intention to adopt digital banking (Raza et al., 2019). The easier the digital banking operation, the higher the intention to use this technology will be. Thus, the following hypothesis is proposed:

H2: Effort Expectancy (EE) has a positive effect on behavioral intention (BI) in using digital banking service of Islamic banks.

According to Venkatesh et al. (2012) social influence (SI) is defined as the extent to which individuals believe that people who are important to them think that they must use technology. SI shows that technology adoption depends on the individual's belief about what and how their siblings feel about technology adoption (Nawaz et al., 2020). The role of SI in increasing consumers' intention in digital banking has been widely analyzed in previous studies (Alalwan, 2018; Nawaz et al., 2020; Raza et al., 2019; Rahi et al., 2018). The study conducted by Akhtar et al. (2019) shows the intention to use digital banking in a cultural context influenced by the closest people, and specifically SI has a higher effect in Pakistan than in China. Thus, the hypothesis is proposed as follows:

H3: Social Influence (SI) has a positive effect on behavioral intention (BI) in using digital banking service of Islamic banks.

The technical support available to individuals while using technology is called the Facilitating Condition (FC) (Venkatesh et al., 2003). According to Hassanudin et al. (2019) in the context of internet banking, individuals need support or guidance in terms of usage skills, facility descriptions, security, FAQs, etc. According to Alalwan (2018), Johar \& Suhartanto (2019) and Nawaz et al. (2020), FC has an impact on behavioral intention and sustainable use of digital banking. The better the availability of FC support for customers, the higher the willingness to use and to adopt the technology (Hassanudin et al., 2019). Therefore, the hypothesis is proposed as follows:

H4: Facilitating Condition (FC) has a positive effect on behavioral intention (BI) in using digital banking service of Islamic banks. 
According to Venkatesh et al. (2012) habit $(\mathrm{Hb})$ reflects the repetition of certain actions based on individuals' knowledge and experience. A study conducted by Hassanudin et al. (2019) shows that $\mathrm{Hb}$ has a positive impact on the intention to use digital banking. This is in line with the research conducted by Nawaz et al. (2020), Venkatesh et al. (2012) and Venkatesh et al. (2016) stating that habit is a significant variable in influencing consumers' intention to use technology. This habit is formed when the behavior often repeats itself in a stable context and when the behavior leads to satisfactory results (Thøgersen \& Møller, 2008). Thus, the more the individuals get used to using digital banking, the higher their intention to continue using this technology. Thus, the hypothesis is proposed as follows:

$\mathrm{H} 5$ : Habit $(\mathrm{Hb})$ has a positive effect on behavioral intention (BI) in using digital banking service of Islamic banks.

Trust (Tr) can be defined as an individual's desire to accept vulnerability based on positive expectation about their behavioral intention in an interdependent and risky situation (Kaabachi et al., 2019). Trust is a subjective belief that a party will fulfil its obligations. This is very important in electronic financial transaction, where users are vulnerable to the risk of uncertainty and loss (Slade et al., 2015). Trust is the main factor influencing user's attitude towards technology adoption (Alharbi, 2017). According to Akhtar et al. (2019), customer trust in the banks is preferred to build long-term relationship and to gain high loyalty. It is proven that Trust has a significant positive effect on behavioral intention to use technology (Akhtar et al., 2019; Alharbi, 2017; Slade et al., 2015). The more the customers trust in the digital banking service of Islamic banks, the more their intention to use it. Thus, the hypothesis is proposed as follows:

H6: Trust has a positive effect on behavioral intention (BI) in using digital banking service of Islamic banks.

In the context of technology, satisfaction (St) is defined as the level of user satisfaction with reports, websites, and service support (Albashrawi et al., 2019). Satisfaction can also be defined as an individual reaction to the product used. Satisfaction can be seen from indicators of usefulness, effectiveness, efficiency, and performance of a product (Wijayanti \& Riza, 2017). User satisfaction is concluded based on the experience in using a product (Sahin et al., 2011). Satisfaction is an important factor for predicting behavioral intention in using information technology (Chao, 2019). Thus, the more satisfied the customers with digital banking, the higher their intention to continue using this technology. Thus, the hypothesis is proposed as follows:

H7: St has a positive effect on behavioral intention (BI) in using digital banking service of Islamic banks.

\section{Research Methods}

This research is a descriptive-exploratory research that uses a quantitative approach supported by qualitative data. In the first study, it aims to describe the phenomenon of digital banking adoption during the COVID-19 pandemic. Data collection was conducted through survey by providing closed questions to measure people's perceptions of acceptance, trust, and satisfaction of the digital banking service of Islamic banks. After that, in the second study, the researcher gave open questions to explore the potential constructs for the UTAUT model development in the context of Islamic banks. In the third study, the researchers dig up information to come up with policy advice for improving the digital banking service of Islamic banks.

The population of this study was an infinite population, who were users of digital banking service of Islamic banks in the early semester of 2020 (during the COVID-19 Pandemic without the total number of pollution). This study used a non-probability sampling method applying purposive sampling technique with judgmental sampling type to obtain respondents who fit the research criteria (Cooper \& Schindler, 2011). As for the first criterion, respondents were users of digital banking service of Islamic banks; the second criterion was that they used digital banking services during the COVID-19 pandemic. The researchers were assisted by enumerators throughout Indonesia and online questionnaires using Google Forms. 
In the first study, each variable in UTAUT2 was measured using a modified instrument developed by Venkatesh et al. (2003), Venkatesh (2012) and Venkatesh et al. (2016), where PE, $\mathrm{EE}, \mathrm{SI}$, and FC were each measured using 5 question items, Hb was measured using 4 question items, and BI was measured using 6 question items. Trust is a subjective belief that a party will fulfil its obligations (Slade et al., 2015). Trust variable is measured using an instrument of Sahin et al. (2011) consisting of 3 question items. Meanwhile, satisfaction is the conformity between expectation and service reality. This study used an instrument of Sahin et al. (2011) and Wijayanti \& Riza (2017) consisting of 8 question items. All items used a 5-point Likert scale from "strongly disagree" to "strongly agree".

The research model and the relationship among variables were tested using the Partial Least Square-Structural Equation Model (PLS-SEM) method assisted by the WarpPLS 7.0 software. Before testing the hypothesis, the outer \& inner model was tested, and the researcher paid attention to the Goodness of Fit $(\mathrm{GoF})$ criteria to ensure the suitability between the data and the measurement model (Jaradat \& Al Rababaa, 2013). Reliability and validity tests were conducted by using Cronbach $\alpha$ value, Average Variance Extracted (AVE), and Confirmatory Factor Analysis (CFA), which were carried out by eliminating scores below 0.06 and were not grouped on specific factors (Hair et al., 2010). Meanwhile, in the second and third studies, researchers used SPSS 23 software to analyze data from open questions descriptively (Wijayanti \& Riza, 2017).

\section{Result and Discussion}

Table 1. Respondents' Demographic Profile

\begin{tabular}{|c|c|c|c|}
\hline Variable & Description & $\mathbf{N}$ & $(\%)$ \\
\hline \multirow[t]{2}{*}{ Gender } & Male & 300 & $35,5 \%$ \\
\hline & Female & 545 & $64,5 \%$ \\
\hline \multirow[t]{4}{*}{ Age } & $\leq 20$ & 369 & $43,7 \%$ \\
\hline & $21-30$ & 415 & $49,1 \%$ \\
\hline & $31-40$ & 26 & $3,1 \%$ \\
\hline & $\geq 41$ & 35 & $4,1 \%$ \\
\hline \multirow[t]{3}{*}{ Educational Level } & High school/equivalent & 201 & $23,8 \%$ \\
\hline & $\mathrm{D} 3 / \mathrm{S} 1$ & 615 & $72,8 \%$ \\
\hline & $\mathrm{S} 2 / \mathrm{S} 3$ & 29 & $3,4 \%$ \\
\hline \multirow[t]{6}{*}{ Occupation } & Student & 559 & $66,2 \%$ \\
\hline & Private Employee & 145 & $17,2 \%$ \\
\hline & Professional & 28 & $3,3 \%$ \\
\hline & Government Employee & 54 & $6,4 \%$ \\
\hline & Entrepreneur & 43 & $5,1 \%$ \\
\hline & Other & 16 & $1,9 \%$ \\
\hline \multirow[t]{5}{*}{ Monthly Income } & $<$ Rp.1.500.000 & 551 & $65,2 \%$ \\
\hline & Rp.1.500.001-Rp.5.000.000 & 234 & $27,7 \%$ \\
\hline & Rp.5.000.001-Rp.10.000.000 & 40 & $4,7 \%$ \\
\hline & Rp.10.000.001-Rp.15.000.000 & 6 & $0,7 \%$ \\
\hline & $>$ Rp.15.000.000 & 14 & $1,7 \%$ \\
\hline \multirow[t]{7}{*}{ Islamic Bank } & BSM & 322 & $38,1 \%$ \\
\hline & BNI Syariah & 259 & $30,7 \%$ \\
\hline & BRI Syariah & 175 & $20,7 \%$ \\
\hline & Muamalat & 40 & $4,7 \%$ \\
\hline & BPD Syariah & 20 & $2,4 \%$ \\
\hline & BCA Syariah & 13 & $4,7 \%$ \\
\hline & Other Islamic banks & 16 & $1,9 \%$ \\
\hline Duration of use DB & $<6$ Months & 223 & $26,4 \%$ \\
\hline \multirow[t]{4}{*}{ Islamic Bank } & 6 Months -1 Year & 244 & $28,9 \%$ \\
\hline & 1 Year -2 Years & 228 & $27 \%$ \\
\hline & 2 years -3 Years & 78 & $9,2 \%$ \\
\hline & $>3$ Years & 72 & $8,5 \%$ \\
\hline
\end{tabular}

Source: (Data processing)

The number of respondents in this study is 845 customers of Islamic banks. The characteristics of the respondents in this study are quite varied with the scattered demographics and various 
Digital Banking (DB) providers in various durations of using Digital Banking services. This research data show a good sampling with respondents scattered in various cities in Indonesia.

\section{First Study (Measurement Models and Assessment of Structural model)}

Table 2. Validity and Reliability Test Results

\begin{tabular}{|c|c|c|c|c|}
\hline Code & Item Variable & Loading & CA \& CR & AVE \\
\hline & Performance Expectancy (PE) & & 0,905 & 0,725 \\
\hline PE1 & DB of the Islamic Bank $\mathrm{X}$ is useful for my daily life & 0,858 & 0,929 & \\
\hline PE2 & DB of the Islamic Bank X helps me get things done faster & 0,887 & & \\
\hline PE3 & DB of the Islamic Bank X helps improve my productivity & 0,853 & & \\
\hline PE4 & DB of the Islamic Bank X enables me to organize my bank account anytime & 0,803 & & \\
\hline \multirow[t]{2}{*}{ PE5 } & $\begin{array}{l}\text { DB of the Islamic Bank } \mathrm{X} \text { helps me improve my effectiveness in running } \\
\text { activities and work }\end{array}$ & 0,856 & & \\
\hline & Effort Expectancy (EE) & & 0,948 & 0,829 \\
\hline EE1 & It is easy for me to learn to operate DB of the Islamic Bank $\mathrm{X}$ & 0,905 & 0,960 & \\
\hline EE2 & The use of DB of the Islamic Bank $\mathrm{X}$ is simple and easy to understand & 0,923 & & \\
\hline EE3 & DB of the Islamic Bank $\mathrm{X}$ is easy to use & 0,934 & & \\
\hline EE4 & It is easy for me to operate DB of the Islamic Bank X & 0,923 & & \\
\hline \multirow[t]{2}{*}{ EE5 } & I find it flexible to use DB of the Islamic Bank X & 0,865 & & \\
\hline & Social Influence (SI) & & 0,837 & 0,610 \\
\hline SI1 & The closest one to me thinks that I should use DB of the Islamic Bank X & 0,832 & 0,885 & \\
\hline SI2 & $\begin{array}{l}\text { The one who influences me a lot thinks that I should use DB of the Islamic } \\
\text { Bank X }\end{array}$ & 0,862 & & \\
\hline SI3 & The one whose opinion I respect prefers using DB of the Islamic Bank X & 0,846 & & \\
\hline SI4 & My work or study environment supports the use of DB of the Islamic Bank X & 0,678 & & \\
\hline \multirow[t]{2}{*}{ SI5 } & My friends use DB of the Islamic Bank X & 0,663 & & \\
\hline & Facilitating Condition (FC) & & 0,873 & 0,664 \\
\hline FC1 & I have the necessary resources to use DB of the Islamic Bank X & 0,793 & 0,908 & \\
\hline FC2 & I have the necessary knowledge to use DB of the Islamic Bank X & 0,819 & & \\
\hline FC3 & DB of the Islamic Bank X is compatible with my Smartphone & 0,852 & & \\
\hline FC4 & I can get help when facing trouble in using DB of the Islamic Bank X & 0,802 & & \\
\hline \multirow[t]{2}{*}{ FC5 } & $\begin{array}{l}\text { All contents of service of DB of the Islamic Bank X are easy to read and to } \\
\text { understand }\end{array}$ & 0,807 & & \\
\hline & Habit $(\mathrm{Hb})$ & & 0,855 & 0,699 \\
\hline Hb1 & Using DB of the Islamic Bank X has become a habit for me & 0,896 & 0,902 & \\
\hline $\mathrm{Hb} 2$ & I have to use DB of the Islamic Bank X for my activities/work & 0,847 & & \\
\hline $\mathrm{Hb} 3$ & Using DB of the Islamic Bank $\mathrm{X}$ has become a common thing for me & 0,862 & & \\
\hline \multirow[t]{2}{*}{$\mathrm{Hb} 4$} & I am addicted to using DB of the Islamic Bank X & 0,732 & & \\
\hline & Trust $(\mathrm{Tr})$ & & 0,869 & 0,793 \\
\hline $\operatorname{Tr} 1$ & $\begin{array}{l}\text { I trust the personal information given for transaction using DB of the Islamic } \\
\text { Bank X }\end{array}$ & 0,849 & 0,920 & \\
\hline $\operatorname{Tr} 2$ & Using DB of the Islamic Bank $\mathrm{X}$ is safe & 0,903 & & \\
\hline \multirow[t]{2}{*}{$\operatorname{Tr} 3$} & My personal information will be safe when using DB of the Islamic Bank X & 0,918 & & \\
\hline & Satisfaction $(\mathrm{St})$ & & 0,956 & 0,792 \\
\hline St1 & I am satisfied with the services provided by $\mathrm{DB}$ of the Islamic Bank $\mathrm{X}$ & 0,892 & 0,964 & \\
\hline St2 & I am satisfied with DB of the Islamic Bank X & 0,908 & & \\
\hline St3 & I enjoy using DB of the Islamic Bank X & 0,906 & & \\
\hline St4 & DB performance of the Islamic Bank X can fulfil my needs & 0,906 & & \\
\hline St5 & Services provided by DB of the Islamic Bank X are very satisfying & 0,890 & & \\
\hline St6 & Using DB of the Islamic Bank $\mathrm{X}$ is a satisfying experience & 0,887 & & \\
\hline \multirow[t]{2}{*}{ St7 } & I made the right decision to use $\mathrm{DB}$ of the Islamic Bank $\mathrm{X}$ & 0,838 & & \\
\hline & Behavioral Intention (BI) & & 0,915 & 0,704 \\
\hline BI1 & $\begin{array}{l}\text { I will use DB of the Islamic Bank X if DB of the Islamic Bank X can be used } \\
\text { in my workplace }\end{array}$ & 0,715 & 0,934 & \\
\hline $\mathrm{BI} 2$ & I will use DB of the Islamic Bank $\mathrm{X}$ in my work as often as needed & 0,867 & & \\
\hline $\mathrm{BI} 3$ & I will use DB of the Islamic Bank X in my work regularly & 0,841 & & \\
\hline BI4 & If possible, I will use DB of the Islamic Bank X in my work & 0,878 & & \\
\hline BI5 & $\begin{array}{l}\text { If possible, I will use DB of the Islamic Bank X for other things outside of my } \\
\text { work }\end{array}$ & 0,851 & & \\
\hline BI6 & If possible, I will use DB of the Islamic Bank X in my work regularly & 0,871 & & \\
\hline
\end{tabular}

Source: (Data processing) 
Before conducting hypothesis testing and model testing, it is necessary to test the reliability and validity of the instrument to obtain reliable and valid data (Cooper \& Schindler, 2011). All variable items in this study are reliable and valid with a Cronbach Alpha value (CA) $\geq 0.70$, Composite Reliability (CR) $\geq 0.70$, Average Variance Extracted (AVE) $\geq 0.50$, and factor loading $\geq 0.60$ except St 8 items are discarded because they do not meet the requirements. The results of these tests are summarized in Table 2.

The results of statistical test show that the value of $\mathrm{R}^{\wedge} 2$ is 0.763 , which means that $\mathrm{BI}$ can be influenced by the variables $\mathrm{PE}, \mathrm{EE}, \mathrm{SI}, \mathrm{FC}, \mathrm{Hb}$, and $\operatorname{Tr}$ by $76 \%$. Meanwhile, the value of $\mathrm{Q}^{\wedge} 2$ is 0.647 , which means that this model is good enough to explain the data using BI construct. Tenehaus GoF model value is $0.745(\geq 0.36=$ large), APC value $0.168 \mathrm{P}<0.001$ (P-value $\leq$ $0.005=$ Fit), ARS value $0.763 \mathrm{P}<0.001$ (P-value $\leq 0.005=$ Fit $),$ AVIF value $2,492(\leq 3.3=$ ideal $)$, and RSCR value is 1,000 (value $=1$ is ideal). The results of this test indicate that this research model is fit according to the rule of thumb, which indicates that this research model is good and acceptable.

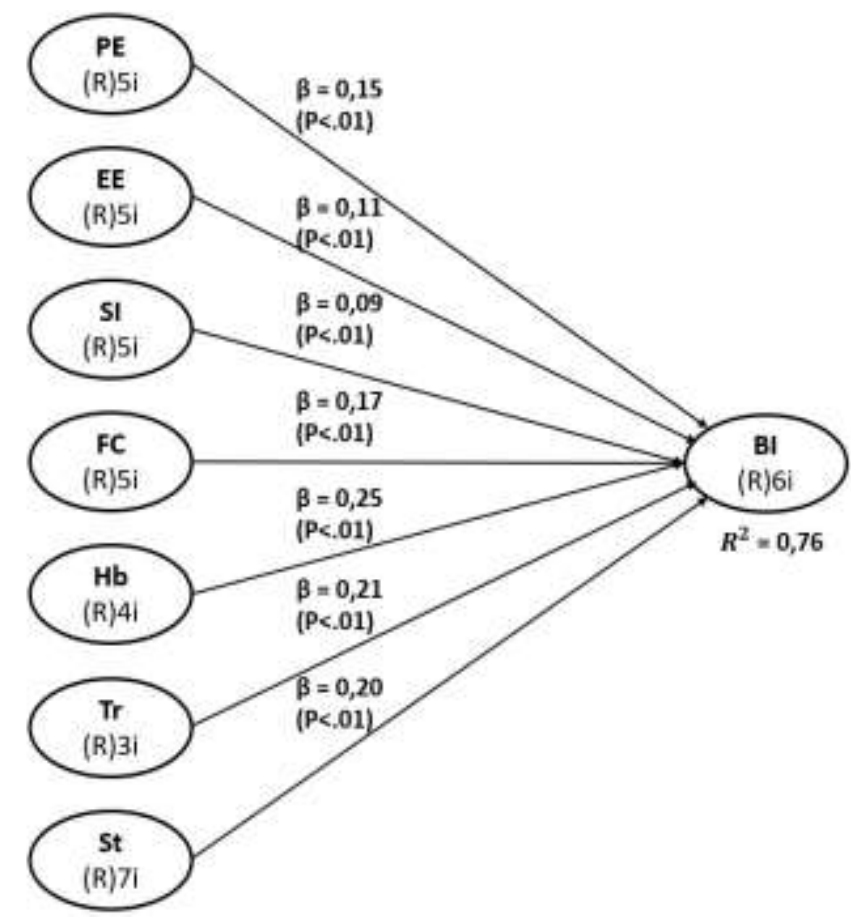

Figure 2. The Results of Structural Model Test for the Acceptance of Digital Banking of Islamic Banks

Figure 2 shows the empirical results in this study. Hypothesis testing is done by looking at the path coefficient to determine the influence of latent variables and p-value for their significance (Mousa Jaradat \& Al Rababaa, 2013). The statistical results show that PE has a significant positive effect on $\mathrm{BI}(\beta=0.15 ; \mathrm{P}<0.01)$, EE has a significant positive effect on $\mathrm{BI}(\beta$ $=0.11 ; \mathrm{P}<0.01)$, SI has a significant positive effect on BI $(\beta=0.09 ; \mathrm{P}<0.01)$, FC has a significant positive effect on $\mathrm{BI}(\beta=0.17$; $\mathrm{P}<0.01)$, Hb has a significant positive effect on $\mathrm{BI}(\beta$ $=0.25 ; \mathrm{P}<0.01)$, Tr also has a significant positive effect on $\mathrm{BI}(\beta=0.21 ; \mathrm{P}<0.01)$, and $\mathrm{St}$ has a significant positive effect on BI $(\beta=0.20 ; \mathrm{P}<0.01)$. Therefore, H1, H2, H3, H4, H5, H6, and $\mathrm{H} 7$ are accepted empirically.

It is proven that the UTAUT2 model is able to predict the adoption and the use of technology in the case of digital banking of Islamic banks (Venkatesh et al., 2012; Venkatesh et al., 2016; Venkatesh et al., 2003). An increase of Trust variable shows a positive result (Akhtar et al., 2019; Alharbi, 2017; Slade et al., 2015) and Satisfaction has a strong influence on Behavioral Intention (Albashrawi et al., 2019; Chao, 2019; Wijayanti \& Riza, 2017).

Based on the results of the data analysis above, it is found that the habit of customers in using digital banking service of Islamic banking is the strongest predictor of the behavior in using 
digital banking technology, where habit is the extent to which individuals tend to behave automatically because of previous learning (Venkatesh et al., 2012). Ajzen (2005) notes that feedback from the previous experience influences belief and behavior in the future. This possibly happens because customers are accustomed to using digital banking before the COVID-19 pandemic, so they have been used to using digital banking during this pandemic. This is indicated by $73.6 \%$ of respondents have used DB of Islamic Bank for more than 6 months.

The next most influential constructs are customer trust and satisfaction. Sequentially, these variables show a high path coefficient value. Alharbi (2017) proves that trust can be a strong predictor and expand the UTAUT model. Alalwan et al. (2015) emphasize that trust is an important element that allows users to adopt technology. According to Chao (2019), trust and satisfaction are critical factors that predict individual adoption of technology. In a research conducted by Wijayanti \& Riza (2017), it is found that customer satisfaction can be a measure of the benefits of Islamic financial technology. It can be concluded that trust and satisfaction with digital banking providers (in this case is Islamic bank) greatly influence customers to continue using this technology.

Confirming previous studies that the constructs of UTAUT, which are performance expectancy, effort expectancy, social influence, and facilitating conditions, are predictors of behavioral intention (Akhtar et al., 2019; Nawaz et al., 2020; Rahi et al., 2019; Venkatesh et al., 2012). This research further strengthens that the UTAUT model, which is a combination of the TRA, TAM, MM, TPB, MPCU, IDT, SCT, and Integrated Model of TAM-TPB theory, has proven robust in explaining technology adoption. Although the values of PE, EE, SI, and FC in this study are lower than $\mathrm{Hb}, \mathrm{Tr}$ and $\mathrm{St}$, the levels of customers in using digital banking of Islamic bank during the COVID-19 pandemic respectively are influenced by customer's habit, confidence, and satisfaction in DB of Islamic bank as well as perceptions of support for Islamic banking technology systems, the use of digital banking, and the ease of technology use. Meanwhile, social influence has the lowest influence on the intention to use DB of Islamic banks.

\section{The Second Study (Open Question Analysis)}

Although the previous studies tried to develop UTAUT and UTAUT2 models in the financial industry by adding Trust (Slade et al., 2015; Alharbi, 2017), Satisfaction (Albashrawi et al., 2019; Chao, 2019), Risk Perception (Dzulhaida \& Giri, 2017), Monthly Expenditure (Jaradat \& Al Rababaa, 2013) power distance, uncertainty evidence (Akhtar et al., 2019), adoption (Thaker, et al., 2019). The researchers have not found a UTAUT model adapted to Islamic economic principles. In this second study, the researchers conduct an exploratory study to find new constructs that have the potential to explain technology acceptance better in the Islamic Finance Industry in general, as well as digital banking of Islamic banks in particular. Based on open questions, several factors that become the main reasons for customers using DB of Islamic banks are summarized in Table 3.

Table 3. Factors Affecting the Use of DB of Islamic Banks

\begin{tabular}{clccllc}
\hline No & \multicolumn{1}{c}{ Factor } & Percentage & No & \multicolumn{1}{c}{ Factor } & Percentage \\
\hline 1 & Ease of Transaction & $25,3 \%$ & 11 & Comfort & $1,7 \%$ \\
2 & Ease of Access & $13,6 \%$ & 12 & Trust & $1,6 \%$ \\
3 & Useful & $11 \%$ & 13 & Service Quality & $1 \%$ \\
4 & Economical & $9,4 \%$ & 14 & Flexible & $0,9 \%$ \\
5 & Avoid Riba & $6,8 \%$ & 15 & Security & $0,9 \%$ \\
6 & Practical & $6,5 \%$ & 16 & Increasing Islamic Economy & $0,7 \%$ \\
7 & Sharia Rules & $5,8 \%$ & 17 & DB Features & $0,7 \%$ \\
8 & Own Desire & $4 \%$ & 18 & Product Variations & $0,5 \%$ \\
9 & Efficient & $3,3 \%$ & 19 & Islamic Bank Promotions & $0,2 \%$ \\
10 & Social Influence & $2,4 \%$ & 20 & Others & $3,7 \%$ \\
\hline
\end{tabular}

Source: (Data processing) 
It is confirmed that several constructs of the UTAUT / UTAUT2 models Venkatesh et al. (2003) and Venkatesh (2012) that become the major factors in DB adoption are the ease of transaction (25.3\%); ease of access (EE) (13.6\%); Helpful (PE) (11\%); Social Influence (SI) (2.4\%); Service Quality (1\%), DB Features (FC) (0.7\%); Practical (6.5\%), Comfort $(1.7 \%)$, Flexible (HM) (0.9\%); Economical (9.4\%), and Efficient (PV) (3.3\%). However, there are several other factors that have not been included in the UTAUT model, such as avoiding riba $(6.8 \%)$, following sharia rules $(5.8 \%)$, and increasing the Islamic economy $(0.7 \%)$. This is in line with Allport's theory of religious orientation regarding intrinsic religiosity. This finding is also supported by Warsame \& Ireri (2018) research that religiosity has an impact on M-Banking adoption. Aji et al. (2020) show that knowledge about riba affects the adoption of E-Money. Samuelson's Preference Theory can illustrate the phenomenon that subjective taste can affect consumption, in this case is Own Desire (4\%). It is found that $1.6 \%$ of respondents use DB because the Trust and Security factor $(0.9 \%)$ of this construct development can refer to the Commitment-Trust Theory for model development. Marketing Mix can also be used as a reference for the UTAUT model development in predicting DB adoption, which is indicated by $0.5 \%$ of Product Variation factor and $0.2 \%$ of Promotion of Islamic banks.

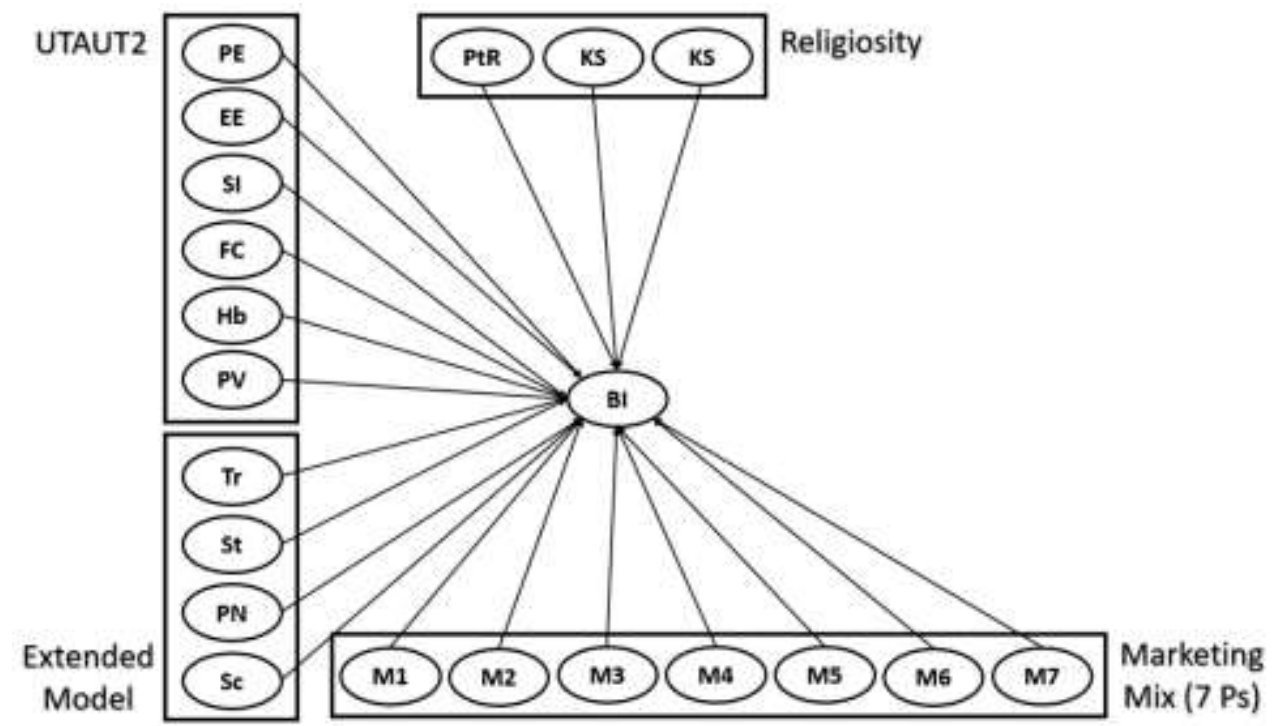

Figure 3. Concept of the UTAUT Model Development of DB of Islamic Banks

Based on the mapping of UTAUT theoretical contribution by Venkatesh et al. (2016), it is suggested that further research use cross-context theory in developing the UTAUT model. Related to the UTAUT development for technology adoption in the Islamic Finance Industry to obtain a more complete model in explaining the adoption of Islamic bank DB technology, the researcher proposes the additional variables of knowledge about riba $(\mathrm{PtR})$, sharia compliance (SC), and the Islamic economic system (IES). In addition, further research can also consider the variable of customer preference $(\mathrm{CP})$, trust $(\mathrm{Tr})$, security $(\mathrm{Sc})$, and marketing mix $(\mathrm{M})$ as the development antecedents of digital banking adoption. Marketing mix that can be used is the one by Kotler, 7Ps Marketing Mix, in order to enrich the model, as seen in Figure 2.

\section{The Third Study (Digital Banking Development of Islamic Banks)}

During the COVID-19 pandemic, technology has created new opportunities for digital financial services to accelerate and to increase financial inclusion during the physical distancing (IMF, 2020). Most banks pay attention to the importance of technology. One of the most developed feature in the Islamic Finance Industry is internet banking/mobile banking (Hassanudin et al., 2019). The very rapid increase in smartphone use has increased the demand for m-banking services. This innovation will increase customer retention, expand client reach, increase market share, provide new job opportunities, and increase efficiency (Akhtar et al., 2019). Therefore, a 
company must continue to innovate and to improve services in order to have a competitive advantage in facing competition.

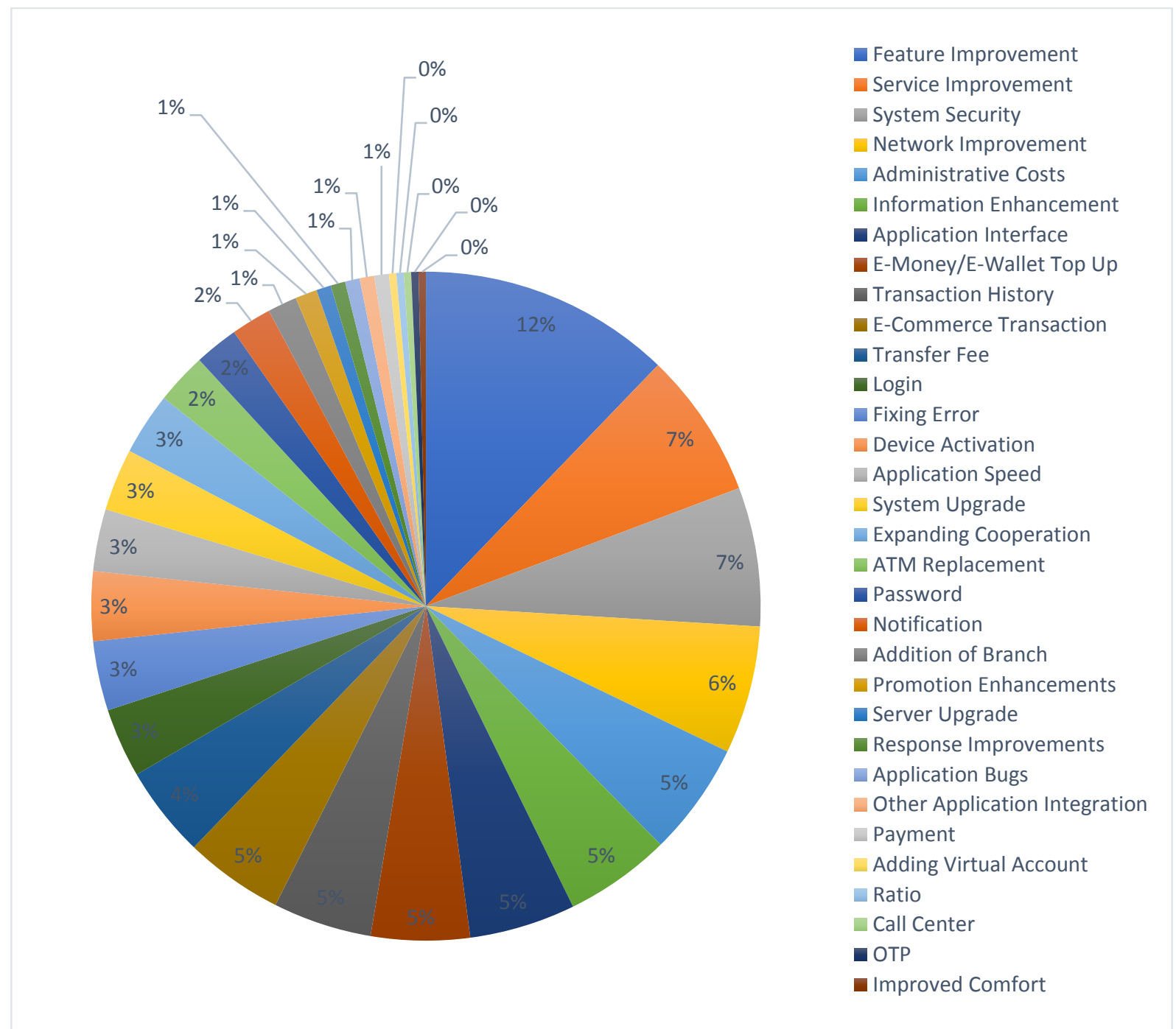

Source: Data processing

Figure 4. Factors that need to be improved in the DB of Islamic Banks

In this third study, researchers conduct an exploratory analysis by involving 845 respondents to find the constraints experienced by customers while using the DB of Islamic banks then the researchers ask their opinions regarding what they expect to overcome these constraints. Most customers are satisfied with the technology and DB services provided by Islamic banks indicated by $43.8 \%$ of respondents who said they are satisfied with the DB used and there is no complaint about using DB. However, an interesting finding about this study is that the researchers found $56.2 \%$ of customers still have complaints and obstacles in using DB. Thus, the respondents provide some opinions/suggestions for improving the quality of DB technology for Islamic banks. Based on these suggestions, the researcher classifies them based on the similarity of customer intentions, so that 32 factors that need to be improved by Islamic banks are summarized in Figure 4.

The researchers group the 32 factors into 7 policy advices for improving digital banking services of Islamic banks, which aims to increase the competitiveness of the Islamic Finance Industry in Indonesia. The advices are provided below:

- DB Feature Development: the Islamic banks need to add more features that are beneficial to customers because features have the highest points in this third study. Those features are e-commerce transaction features, the addition of Virtual Accounts, Top-Up E-Money/E- 
Wallet, integration with other applications, Purchase/Payment features, the substitution of ATM cards, QRIS, more detailed transaction history information, and ZISWAF deposits.

- Application Systems and Networks Improvement: Islamic banks must pay more attention to investment in IT, where customers still find several obstacles related to network disruptions, bugs, slow applications, system \& server upgrades, as well as login problems \& device reactivation.

- Service Improvement: Services should be the pressure point for Islamic banks because the core competence of this business is financial services. However, customers still encounter problems in terms of services such as transaction failures and call center responses. Thus, banks need to increase cooperation with other parties to improve transaction services such as fintech, E-commerce, and taxes.

- Ease of Access Improvement: Ease is the most influential factor in the second study. Islamic banks need to pay attention to this factor in designing their products. It is found that multi-layered passwords are complicated for some customers, as well as the limitations of ATMs and branch offices are still considered as problem. Additional information on access methods is also needed by customers.

- System Security Improvement: Security is very crucial because the risk of digital transactions is very large. Although companies are always improving their security systems, cybercriminals are always looking for ways to commit crimes. Banks need to be aware of various cybercriminals, such as SIM swap and phishing, so they need to protect customer data properly.

- DB Interface Improvement: Currently, customers make more frequent transactions through Digital Banking than at bank offices. Thus, Islamic banks need to continue to improve their appearance to be more attractive, simpler, and less complicated in their use.

- Value for Money Focus: Basically, humans are homo economicus and always see profit and loss, even though sharia principles do not offer that as the first priority. However, customers still consider the transfer fees, the administration fees, the activation fees, and the use of credit at some banks as a burden. Islamic banks are necessary to improve public education regarding this matter and to communicate it in the best possible way.

\section{Conclusion}

It is proven that the UTAUT/UTAUT2 model is able to predict the adoption and the use of digital banking technology of Islamic banks. The additional variables of Trust and Satisfaction show positive results for the development of this model. Based on the data analysis, the customers' habit in using DB is the strongest predictor to the behavior of using DB technology of Islamic banks. The most influential constructs are customers' trust and satisfaction, followed by perceptions to the support of the technology system of Islamic banks, the use of digital banking, the ease of technology use, and the social influence.

Although it is confirmed that several constructs of the UTAUT/UTAUT2 model Venkatesh et al. (2003) and Venkatesh (2012) are the main factors in DB adoption, this exploratory study finds new constructs that have the potential to complement the development of technology acceptance models in the Islamic Finance Industry in general, and DB of Islamic banks in particular. Further research needs to consider the additional variables of knowledge about riba, sharia compliance, and the Islamic economic system, as well as the additional variables of customer preferences, trust, security, and marketing mix as antecedent development of digital banking adoption.

Although most customers are satisfied with the DB technology and service of Islamic banks, which is indicated by $43.8 \%$ of respondents who are satisfied and have no complaints in using DB, this study finds $56.2 \%$ of customers still have complaints and troubles in using DB. Therefore, the respondents expect for the improvement of the quality of DB technology of Islamic banks, which are divided into 32 factors. After that, the researchers group them into 7 policy suggestions for improving the digital banking service of Islamic banks aiming to increase 
the Islamic Finance Industry competitiveness in Indonesia, which are: 1) DB Feature Improvement, 2) System and Network Improvement, 3) Service Improvement, 4) Ease of Access Improvement, 5) Security Improvement, 6) DB Interface Improvement, 7) Value for Money Focus.

This research provides several theoretical and practical contributions. Theoretically, this research provides literature contribution by the confirmation of the UTAUT model modification in the digital banking adoption of Islamic banks during the COVID-19 pandemic. The findings of exploratory studies are related to potential constructs for the development of specific UTAUT models for Islamic financial technology. Practically, this research is able to find obstacles and to provide policy suggestions for improving digital banking services of Islamic banks based on the customers' expectations.

The results of this study can be used as a reference for Islamic Bank managers for making policy and determining strategies in developing digital banking services. It is suggested that the banks need to focus on customers (customer-centric) in improving service quality and digital banking technology in order to minimize the occurrence of Myopic marketing in the formulation of company policies and strategies. The government, as the regulator, needs to pay attention to regulations that can support the increase in cashless transactions using digital banking, and minimize the occurrence of cybercrime, as well as communicate massively the positive impact of digital banking. IMF (2020) claims that digital finance has the potential to help fight the impact of the COVID-19 pandemic and to support economic recovery, where digital finance can ensure access to financial services. However, its role in this recovery phase depends on the industry's resilience to crisis shocks (Sahay et al., 2020). It is necessary that further research considers empirical testing of the modified UTAUT model with the additional variables of knowledge about riba, sharia compliance, and the Islamic economic system, as well as the additional variables of customer preferences, trust, security, and marketing mix as an antecedent development of digital banking adoption and other technology adoption such as Islamic Fintech.

\section{Author Contributions}

Conceptualization: Alex Fahrur Riza

Data curation: Alex Fahrur Riza

Formal analysis: Alex Fahrur Riza

Investigation: Alex Fahrur Riza

Methodology: Alex Fahrur Riza

Project Administration: Alex Fahrur Riza

Supervision: Alex Fahrur Riza

Validation: Alex Fahrur Riza

Visualization: Alex Fahrur Riza

Writing - original draft: Alex Fahrur Riza

Writing - review \& editing: Alex Fahrur Riza

\section{References}

Aji, H.M., Berakon, I., \& Riza, A.F. (2020). The effects of subjective norm and knowledge about riba on intention to use e-money in Indonesia. Journal of Islamic Marketing. https://doi.org/10.1108/JIMA-10-2019-0203

Akhtar, S., Irfan, M., Kanwal, S., \& Pitafi, A.H. (2019). Analysing UTAUT with trust toward mobile banking adoption in China and Pakistan: extending with the effect of power distance and uncertainty avoidance. International Journal of Financial Innovation in Banking, 2(3), 183-207. https://doi.org/10.1504/ijfib.2019.102307

Alalwan, A.A., Rana, N.P., \& Williams, M.D. (2015). Consumer adoption of internet banking in Jordan $\square$ : Examining the role of hedonic motivation, habit, self-efficacy and trust. Journal of Financial Service Marketing, 20 (2), 145-157. https://doi.org/10.1057/fsm.2015.5 
Alalwan, A.A. (2018). Investigating the impact of social media advertising features on customer purchase intention. International Journal of Information Management, 42, 65-77. https://doi.org/10.1016/j.ijinfomgt.2018.06.001

Albashrawi, M., Kartal, H., Oztekin, A., \& Motiwalla, L. (2019). Self-reported and computerrecorded experience in mobile banking: a multi-phase path analytic approach. Information Systems Frontiers, 21, 773-790. https://doi.org/10.1007/s10796-018-9892-1

Alharbi, S. (2017). An extended UTAUT model for understanding of the effect of trust on users' acceptance of cloud computing. International Journal of Computer Applications in Technology, 6(1), 65-76. https://doi.org/10.1504/IJCAT.2017.086562

Amir, M.K.B. \& Bin Amir, M.Z. (2020). COVID-19 Pandemic: Socio-Economic Response, Recovery and Reconstruction Policies on Major Global Sectors. SSRN Electronic Journal, 9(88), 1-27. https://doi.org/10.2139/ssrn.3629670

Bank Indonesia. (2020). Kajian Ekonomi Regional. Laporan Nusantara. Bank Indonesia. https://www.bi.go.id/id/publikasi/kajian-ekonomi-regional/laporannusantara/Pages/Laporan-Nusantara-Agustus-2020.aspx

Chao, C.M. (2019). Factors determining the behavioral intention to use mobile learning: An application and extension of the UTAUT model. Frontiers in Psychology. https://doi.org/10.3389/fpsyg.2019.01652

Cooper, D.R., \& Schindler, P.S. (2011). Business Research Methods. New York, NY: McGraw-Hill.

Databoks.Katadata. Transaksi Digital Menggeser Peran kantor Cabang dan ATM Bank. Retrieved July 20, 2020, from https://databoks.katadata.co.id/datapublish/2019/08/08/transaksidigital-menggeser-peran-kantor-cabang-dan-atm-bank

Decoding The Economics of COVID-19 (2020). Potential Winners \& Losers in The Short Term in Egypt. Retrieved from https://dcodeefc.com/infographics

Detik Finance. Layanan Digital Bank Tumbuh Pesat di Tengah Pandemi. Retrieved Juni 18 2020, from https:// finance.detik.com/moneter/d-5059110/layanan-digital-bank-tumbuh-pesat-ditengah-pandemi

Disemadi, H.S., \& Shaleh, A.I. (2020). Banking credit restructuring policy amid COVID-19 pandemic in Indonesia. Jurnal Inovasi Ekonomi, 5(2), 63-70. https://doi.org/10.22219/jiko.v5i3.11790

Dzulhaida, R., \& Giri, R.R.W. (2017). Analisis minat masyarakat terhadap penggunaan layanan Emoney di Indonesia dengan menggunakan model modifikasi unified theory of acceptance and use technology 2 (UTAUT 2). Majalah Ilmiah UNIKOM, 15(2), 155-166. https://doi.org/10.34010/miu.v15i2.555

Gasser, U., Gassman, O., Hens, T., Leifer, L., Puschman, T., \& Zhao, L. (2017). Digital Banking 2025. Retrieved from http://www.fintech.uzh.ch/dam/jcr:2ef31105

Giri, R. R. W., \& Wellang, K. M. (2016). Impact of website design, trust, and internet skill on the behaviour use of site internet banking in Bandung Raya: A modification of the utaut model. Pertanika Journal of Social Sciences and Humanities, 24, 35050. http://www.pertanika.upm.edu.my/

Hair Joseph F., William C. Black \& Barry J.Babin, A. (2010). Multivariate Data Analysis: A Global Perspective (7th edition). Upper Saddle River, NJ: Pearson Prentice Hall.

Hassanudin, T., Thaker, M., Khaliq, A., \& Hussain, H. (2019). Continuous adoption of internet banking $\square$ : evidence from Islamic banks in Malaysia. Proceedings Manuscript to the $10^{\text {th }}$ Foundation of Islamic Finance Conference advanced Research in Islamic Finance (pp.1-27). Sunway University, Malaysia. Retrieved from http://irep.iium.edu.my/76783 
Icek Ajzen. (2005). Attitudes, Personality and Behavior (2th ed). New York, NY: Open University Press.

Johar, R. S., \& Suhartanto, D. (2019). The adoption of online internet banking in Islamic banking industry. IOP Conference Series: Materials Science and Engineering. https://doi.org/10.1088/1757-899X/662/3/032032

Kaabachi, S., Ben Mrad, S., \& Fiedler, A. (2019). The moderating effect of e-bank structure on French consumers' trust. International Journal of Bank Marketing, 38(2), 501-528. https://doi.org/10.1108/IJBM-04-2019-0119

Otoritas jasa Keuangan. (2018) Penyelenggaraan Layanan Perbankan Digital oleh Bank. Umum. https://www.ojk.go.id/id/regulasi/Pages/Penyelenggaraan-Layanan-Perbankan-Digitaloleh-Bank-Umum.aspx

Thaker, M.T., Pitchay, A., Thaker, H.B., \& Amin, M.F. (2019). Factors influencing consumers' adoption of Islamic mobile banking services in Malaysia: An approach of partial least squares (PLS). Journal of Islamic Marketing, 10(4), 1037-1056. https://doi.org/10.1108/JIMA-04-2018-0065

Thaker, M.T., Amin, M.F., Thaker, H., \& Pitchay, A. (2019). What keeps Islamic mobile banking customers loyal? Journal of Islamic Marketing, 10(2), 525-542. https://doi.org/10.1108/JIMA-08-2017-0090

Jaradat, M.I.R., \& Al Rababaa, M.S. (2013). Assessing key factor that influence on the acceptance of mobile commerce based on modified UTAUT. International Journal of Business and Management, 8(23), 102-112. https://doi.org/10.5539/ijbm.v8n23p102

Nam, K., Lee, Z., \& Lee, B.G. (2016). How internet has reshaped the user experience of banking service? KSII Transactions on Internet and Information Systems, 10(2), 684-702. https://doi.org/10.3837/tiis.2016.02.014

Nawaz, S.S., Hilmy, H.M.A., \& Gunapalan, S. (2020). Islamic banking customers' intention to use mobile banking services: A Sri Lankan study. Journal of Advanced Research in Dynamical and Control Systems, 12(2), 1610-1626. https://doi.org/10.5373/JARDCS/V12I2/S20201200

Nguyen, T.P., Lan, T., \& Dang, P. (2018). Digital banking in Vietnam current situation and recommendations. International Journal of Innovation and Research in Educational Sciences, 5(4), 418-420. Retrieved from https://www.ijires.org/

Rahi, S., Ghani, M., Alnaser, F.M.I., \& Ngah, A.H. (2018). Investigating the role of unified theory of acceptance and use of technology (UTAUT) in internet banking adoption context. Management Science Letters, 8(3), 173-186. https://doi.org/10.5267/j.msl.2018.1.001

Raza, S. A., Shah, N., \& Ali, M. (2019). Acceptance of mobile banking in Islamic banks: evidence from modified UTAUT model. Journal of Islamic Marketing, 10(1), 357-376. https://doi.org/10.1108/JIMA-04-2017-0038

Riza, A. F. (2019). Customer acceptance of digital banking in Islamic bank: Study on millennial generation. Proceeding of Conference on Islamic Management, accounting, and Economics (pp. 66-74), Indonesia, Retrieved from https://journal.uii.ac.id/CIMAE/article/view/13351

Riza, A. F., \& Hafizi, R. (2019). Customers attitude toward Islamic mobile banking in Indonesia $\square$ : Implementation of TAM. Asian Journal of Islamic Management (AJIM), 1(2), 75-84. https://doi.org/10.1108/AJIM.vol1.iss2.art1

Roubini, N., (2020). The Coming Greater Depression of the 2020s. Project Syndicate. Retrieved April 28, 2020. from https://www.project-syndicate.org/commentary/greater-depression-covid19headwinds-bynouriel-roubini-2020-04

Sahay, R., \& Allmen, U.E.V., Lahreche, A., Khera, P., Ogawa, S., Bazarbash, M., \& Beaton, K. (2020). The Promise of Fintech $\square$ : Financial Inclusion in the Post COVID-19 Era. IMF Departmental Papers/Policy Papers 20/09, International Monetary Fund. 
https://EconPapers.repec.org/RePEc:imf:imfdep:20/09

Sahin, A., Zehir, C., \& Kitapçi, H. (2011). The effects of brand experiences, trust and satisfaction on building brand loyalty; an empirical research on global brands. Procedia - Social and Behavioral Sciences, 24, 1288-1301. https://doi.org/10.1016/j.sbspro.2011.09.143

Sembiring, M. J. Fatihudin, D., Mochklas, M., Holisin, I. (2020). Banking employee performance during pandemic Covid-19 $\square$ : remuneration and motivation. Journal of Xi'an University of Architecture \& Technology, XII(VII), 64-71. Retrieved from http://xajzkjdx.cn/gallery/5july2020a.pdf

Slade, E.L., Dwivedi, Y.K., Piercy, N.C., \& Williams, M.D. (2015). Modeling consumers' adoption intentions of remote mobile payments in the United Kingdom: Extending UTAUT with innovativeness, risk, and trust. Psychology and Marketing, 32(8), 860-873. https://doi.org/10.1002/mar.20823

Syed, M., Khan, S., Rabbani, Musthafa, T., \& Yannis. (2020). An artificial intelligence and NLP based Islamic FinTech model combining Zakat and Qardh-Al-Hasan for countering the adverse impact of COVID 19 on SMEs and individuals. International Journal of Economics and Business Administration, 8(2), 351-364. https://doi.org/10.35808/ijeba/466

Thøgersen, J., \& Møller, B. (2008). Breaking car use habits: The effectiveness of a free one-month travelcard. Transportation, 35(3), 329-345. https://doi.org/10.1007/s11116-008-9160-1

Venkatesh, V., Morris, M.G., Davis, G.B., \& Davis, F.D. (2003). User acceptance of information technology: Toward a unified view. MIS Quarterly, 27(3), 425-478. https://doi.org/10.2307/30036540

Venkatesh, V., Thong, J.Y.L., \& Xu, X. (2012). Consumer acceptance and use of information technology: Extending the unified theory of acceptance and use of technology. MIS Quarterly, 36(1), 157-178. https://doi.org/10.2307/41410412

Venkatesh, V., Thong, J.Y.L., \& Xu, X. (2016). Unified theory of acceptance and use of technology: A synthesis and the road ahead. Journal of the Association for Information Systems, 17(5), 328-376. Retrieved from http://ais.site-ym.com/?SeniorScholarBasket

Venkatesh, V., \& Davis, F.D. (2000). A Theoretical extension of the technology acceptance model: four longitudinal field. Management Science 46 (2), 186-204. https://doi.org/10.1287/mnsc.46.2.186.11926

Venkatesh, V., Davis, F. D., \& Morris, M. G. (2007). Dead or alive? The development in trajectory and future of technology adoption research. Journal of The Association for Information Systems, 8(4), 1. http://aisel.aisnet.org/jais/vol8/iss4/1

Warsame, M.H., \& Ireri, E.M. (2018). Moderation effect on mobile microfinance services in Kenya:An extended UTAUT model. Journal of Behavioral and Experimental Finance, 18(C), 67-75. https://doi.org/10.1016/j.jbef.2018.01.008

Wijayanti, D.M., \& Riza, A.F. (2017). Sharia Fintech: Positive innovation in consumer perspective. Proceeding of International Seminar Academic Network on Competition Policy (pp.101-119), Nusa Dua, Bali. Retrieved from http://eprints.undip.ac.id/66376/1/Prosiding_PKPU.pdf\#page=103

Winarsih, I.M., \& Fuad, K. (2020). Impact of covid-19 on digital transformation and sustainability in small and medium enterprises (smes): a conceptual framework. Advances in Intelligent Systems and Computing. https://doi.org/10.1007/978-3-030-50454-0_48

Worldometer. COVID-19 Corona Virus Pandemic. Retrieved July 20, 2020, from https://www.worldometers.info/coronavirus/

World Health Organization. Global Research on Coronavirus disease (COVID-19). from https://www.who.int/emergencies/diseases/novel-coronavirus-2019/global-researchon-novel-coronavirus-2019-ncov 